\title{
Persepsi Petani Terhadap Peran Tenaga Pendamping Mahasiswa / Alumni Pada Program Upaya Khusus Peningkatan Produksi Padi, Jagung, Kedelai (Upsus - Pajale) Di Kabupaten Nagan Raya \\ (Farmers Perception Of Role associate personnel Student / Alumni On Production Improvement Program Special Effort Rice, Corn, Soybeans (Upsus - Pajale) In Nagan Raya)
}

\author{
Dedy Irmayanda ${ }^{1}$, Azhar $^{1}$, Zakiah $^{1}$ \\ ${ }^{1}$ Program Studi Agribisnis, Fakultas Pertanian, Universitas Syiah Kuala
}

\begin{abstract}
Abstrak- Peran pendamping merupakan kegiatan yang dilakukan dilapangan bersama penyuluh dalam meningkatkan efektivitas pelaksanaan program dan kegiatan percepatan pencapaian swasembada padi, jagung dan kedelai di sentrasentra produksi dengan melibatkan mahasiswa alumni, dosen serta tenaga pemantau/supervisor, Tujuan dari penelitian ini mengetahui persepsi petani terhadap peran tenaga pendamping mahasiswa alumni pada program UPSUSPAJALE di Kabupaten Nagan Raya. Penelitian ini dilakukan dengan metode survey. Analisis yang digunakan pada dalam penelitian ini yaitu analisis deskriptif. Hasil penelitian ini menunjukkan bahwa berdasarkan analisis deskriptif yang dilakukan maka persepsi petani terhadap tenaga pendamping (Mahasiswa dan Alumni) telah berperan baik pada Program UPSUS PAJALE di kabupaten Nagan Raya.
\end{abstract}

\section{Kata Kunci: Program Upsus, Peran Pendamping, Padi, Jagung dan Kedelai}

Abstract -The co-laborers' role is an activity which is conducted together in the field in collaboration with the extension agents in improving the effectiveness of the implementations of programs accelerating self-sufficiency programs of rice, corn, and soybean in the production centers by involving university students/ alumni, lecturers as well as supervisors. The purpose of this study is to know the farmers' perceptions towards the role of university students/ alumni as the colaborers participating in UPSUS-PAJALE in Nagan Raya. This study was conducted using survey method. The analysis used in this study was descriptive analysis. Based on the descriptive analysis conducted, the results show that farmers' agree that the existence of co-laborers program (university students and alumni) has contributed well to UPSUS PAJALE program in Nagan Raya.

\section{Keywords: UPSUS Program, Farmers' Perception, Co-laborers Role, Rice,} Corn, and Soybean. 


\section{PENDAHULUAN}

Indonesia merupakan Negara agraris dan sebagian besar penduduknya bermata pencaharian di bidang pertanian. Kebutuhan pangan nasional terus meningkat, tetapi dilain pihak ketersediaan lahan pertanian terus menyempit akibat alih fungsi lahan untuk pembangunan sektor lain seperti: pemukiman, industri dan infrastuktur. Berkurangnya lahan pertanian produktif ditambah dengan anomali iklim akibat pemanasan global telah menyebabkan berkurangnya pasokan pangan (food shortage) dan harga pangan yang terus meningkat.

Pemerintah telah mengantisipasi kondisi tersebut melalui program upaya khusus (UPSUS) untuk swasembada berkelanjutan pangan nasional. Program upsus tersebut hanya untuk tiga komoditas utama yaitu padi, jagung, dan kedelai (PAJALE) dalam rangka mensukseskan kedaulatan pangan dalam tiga tahun mendatang di era pemerintahan Presiden Jokowi yang dilaksanakan serentak di beberapa provinsi di Indonesia, salah satunya adalah di Provinsi Aceh. Program Upsus juga mendapat dukungan dari TNI Angkatan Darat, yaitu dengan ditandatanganinya MOU antara Menteri Pertanian RI dengan Kepala Staf Angkatan Darat (KSAD) bahwa seluruh BABINSA akan membantu petani agar program swasembada pangan ini dapat terwujud pada tahun 2017 (Kurniawan, 2015).

Menurut Robbins (2003) yang mendeskripsikan bahwa persepsi merupakan kesan yang diperoleh oleh individu melalui panca indera kemudian di analisa (diorganisir), diintepretasi dan kemudian dievaluasi, sehingga individu tersebut memperoleh makna. Persepsi Petani terhadap Program Upsus adalah respon langsung dari petani tentang bagaimana keberhasilan Progam Upsus dan apakah dengan adanya program tersebut dapat diterima atau tidak. Keberhasilan peran pendamping mahasiswa dapat dinilai dari respon atau persepsi dari petani tersebut.

Peran pendamping merupakan kegiatan yang dilakukan dilapangan bersama penyuluh dalam meningkatkan efektivitas pelaksanaan program dan kegiatan percepatan pencapaian swasembada padi, jagung dan kedelai di sentra-sentra produksi dengan melibatkan mahasiswa/alumni, dosen serta tenaga pemantau/supervisor. Departemen Sosial (2005), pendampingan adalah proses pembimbingan atau pemberian kesempatan kepada masyarakat, khususnya masyarakat miskin yang dilakukan oleh para pendamping atau fasilitator melalui serangkaian aktivitas yang memungkinkan komunitas tersebut memiliki kemampuan dan kepercayaan diri dalam menghadapi permasalahan di seputar kehidupannya. Pendampingan sebagai suatu strategi yang umum digunakan oleh pemerintah dan lembaga non profit dalam upaya meningkatkan mutu dan kualitas dari sumber daya manusia, sehingga mampu mengindentifikasikan dirinya sebagai bagian dari permasalahan yang dialami dan berupaya untuk mencari alternatif pemecahan masalah yang dihadapi. Kemampuan sumber daya manusia sangat dipengaruhi oleh keberdayaan dirinya sendiri. Oleh karena itu sangat dibutuhkan kegiatan pendampingan. Pendampingan merupakan suatu strategi yang sangat menentukan keberhasilan program pemberdayaan masyarakat (Suharto, 2005). 
Meskipun program pendampingan telah dilakukan namun kenyataannya belum ada sebuah kajian khusus yang mengkaji mengenai peran pendampingan. Oleh karena itu, penulis tertarik untuk mengkaji bagaimana persepsi petani terhadap peran tenaga pendamping mahasiswa pada program upaya khusus peningkatan produksi padi, jagung, kedelai (upsus-pajale) di Kabupaten Nagan Raya.

Tujuan penelitian ini adalah untuk mengetahui persepsi petani terhadap peran tenaga pendamping mahasiswa/alumni berperan baik pada program UPSUS-PAJALE di Kabupaten Nagan Raya.

\section{METODE PENELITIAN}

Metode yang digunakan pada penelitian ini yaitu metode survey. Metode survey adalah penyelidikan yang diadakan untuk memperoleh fakta-fakta dari gejala-gejala yang ada dan mencari keterangan-keterangan secara aktual baik tentang institusi sosial dan ekonomi dari suatu kelompok atau dari suatu daerah (Nazir, 2005). Populasi pada penelitian ini yaitu semua petani yang menerima Program UPSUS. Jumlah populasi pada penelitian ini adalah 50 orang petani. Petani tersebut tersebar di 4 Kecamatan yaitu Kecamatan Suka Makmue, Kecamatan Tripa Makmue, Kecamatan Tadu Raya, Kecamatan Darul Mamur. Penentuan sampel dilakukan dengan teknik pengambilan sampel secara sensus (Sampling Jenuh). Sampling jenuh adalah teknik penentuan sampel apabila semua anggota populasi digunakan sebagai sampel. Biasanya dilakukan jika populasi dianggap kecil atau kurang dari 100 (Sugiyono, 2005). Berdasarkan pendapat tersebut maka jumlah sampel pada penelitian ini adalah 50 orang petani diambil dari keseluruhan populasi.

Model analisa data yang digunakan untuk mengetahui pengetahuan petani tentang persepsi petani terhadap peran pendamping mahasiswa/alumni dalam keberhasilan penyuluh petani padi, jagung, dan kedelai dan juga dengan melihat tugas pokok dan fungsi (TUPOKSI) pendampingan dalam Program UPSUS PAJALE. Analisis data dilakukan dengan menggunakan analisis deskriptif. Deskriptif yaitu teknik mengumpulkan, mengelola, menyajikan dan menjabarkan hasil penelitian sesuai informasi yang di dapatkan peneliti dilapangan. Data yang diperoleh akan dipaparkan dan dianalisis dengan menggunakan Tabel tunggal, sehingga data dapat dibaca dengan mudah untuk mengetahui jawaban dari masalah yang diteliti (Sugiyono, 2011). Skala pengukuran yang digunakan yaitu skala pengukuran likert. Dengan skala likert variabel yang tidak dapat diukur dijabarkan menjadi komponen yang dapat diukur. Komponen yang dapat diukur ini dijadikan sebagai tolak ukur untuk menyusun item instrumen dapat berupa pertanyaan dan dijawab oleh responden. Jawaban dari setiap pertanyaan tersebut digolongkan menjadi 5 golongan yaitu sangat setuju $=$ skor 5 , setuju $=$ skor 4 , kurang setuju $=$ skor 3 , tidak setuju $=$ skor 2 , sangat tidak setuju $=$ skor 1 . Untuk mengetahui kategori data skor maka perhitungan nya adalah sebagai berikut: 
Rentang skor $=\frac{\text { (jumlah skor tertinggi - jumlah skor terendah) }}{2}$

$$
\begin{aligned}
& =\frac{30-6}{2} \\
& =\frac{24}{2} \\
& =12
\end{aligned}
$$

Total score $6-18=$ katergori 0 (tidak berperan baik berdasarkan persepsi petani)

Total score $19-30=$ kategori 1(berperan baik berdasarkan persepsi petani)

\section{Kriteria Penentuan Hipotesis}

Batas atas = jumlah pertanyaan $\mathrm{x}$ skor tertinggi

$$
=6 \times 5
$$

$=30$

$=\frac{30}{30} \times 100 \%=100 \%$

Batas bawah $=$ jumlah pertanyaan $\mathrm{x}$ skor terendah

$$
=6 \times 1
$$$$
=6
$$$$
=\frac{6}{30} \times 100 \%=20 \%
$$

Range $(\mathrm{R}) \quad=$ skor tertinggi - skor terendah

$$
\begin{aligned}
& =100 \%-20 \% \\
& =80 \%
\end{aligned}
$$

Kategori $(\mathrm{K})=$ berperan baik $=1$ tidak berperan baik $=0$

Interval $\quad=\frac{R}{K}=80 \% / 2=40 \%$

Skor standar $=100 \%-40 \%=60 \%$

Kriteria objektif :

Hipotesis $0=$ Tenaga pendamping tidak berperan baik terhadap Program Upsus

Hipotesis a $\quad=$ Tenaga pendamping berperan baik terhadap Program Upsus

Kriterial pengujian hipotesis

Terima $\mathrm{H}_{0}=$ jika kategori $1 \leq 60 \%$, maka tenaga pendamping tidak berperan baik terhadap Program Upsus.

Terima $\mathrm{H}_{\mathrm{a}}=$ jika kategori $1>60 \%$, maka tenaga pendamping berperan baik terhadap Program Upsus.

\section{HASIL DAN PEMBAHASAN}

Program UPSUS PAJALE merupakan salah satu program yang diterapkan oleh pemerintah secara khusus dalam hal peningkatan produksi padi, jagung dan kedelai. Persepsi petani terhadap peran tenaga pendamping mahasiswa/alumni 
sangat diharapkan dalam keberhasilan program tersebut karena keberhasilan program UPSUS dapat meningkatkan kesejahtraan petani khususnya petani padi, jagung dan kedelai.

Untuk melihat berperan baik atau tidaknya tenaga pendamping mahasiwa/alumni terhadap program UPSUS PAJALE tersebut dapat dinilai berdasarkan persepsi atau pendapat dari para petani. Penilaiannya dilakukan dengan cara mengajukan beberapa pertanyaan mengenai peran pendamping mahasiswa/alumni terhadap program UPSUS PAJALE. Jawaban dari setiap pertanyaan tersebut digolongkan menjadi 5 golongan yaitu sangat setuju $=$ skor 5 , setuju $=$ skor 4 , kurang setuju $=$ skor 3 , tidak setuju $=$ skor 2 , sangat tidak setuju $=$ skor 1 .

Total skor yang didapat berdasarkan hasil dari penjumlahan skor pada tiaptiap pertanyaan dapat menjawab hipotesis yang ada. Setelah itu dihitung rentang skornya, maka dapat disimpulkan bahwa total skor 6 sampai 18 digolongkan sebagai katagori 0 (tidak berperan baik) dan total skor 19 sampai 30 digolongkan sebagai katagori 1 (berperan baik). Adapun hasil dari penilitian ini ditabulasikan sebagai berikut :

Tabel 1. Kategori Jumlah dan Presentase Kriteria Peran Pendamping Upsus berdasarkan persepsi petani di Kabupaten Nagan Raya Tahun 2015

\begin{tabular}{|c|c|c|}
\hline Kategori & Jumlah (orang) & Persentase $(\%)$ \\
\hline 1 (Berperan Baik) & 41 & 82 \\
\hline 0 (Tidak Berperan Baik) & 9 & 18 \\
\hline Total & 50 & 100 \\
\hline
\end{tabular}

Sumber: Data Primer (2014)

Berdasarkan kriteria penerimaan hipotesis, dimana jika presentase kategori 1 lebih dari $60 \%$ maka hipotesa alternatif diterima. Persentase peran pendamping pada penelitian ini sebesar $82 \%$ menunjukkan bahwa berdasarkan persepsi petani peran pendamping UPSUS di Kabupaten Nagan Raya sudah baik. Peran tersebut adalah peran yang bersinggungan langsung dengan petani. Suatu peran pendamping mahasiswa dikatakan baik apabila para pendamping mahasiswa tersebut mampu mendongkrak petani untuk menghasilkan produksi yang lebih baik.

Berdasarkan hasil penelitian yang dilakukan untuk pengujian hipotesis maka dapat dijelaskan sebagai berikut :

1. Sebanyak 41 orang responden atau $82 \%$ dari total 50 orang responden yang menjawab kuisioner dengan total score diatas 18. Total score tersebut dikatagorikan 1. 
2. Sebanyak 9 orang responden atau $18 \%$ dari total 50 orang responden yang menjawab kuisioner dengan total score dibawah 18. Total score tersebut dikatagorikan 0 .

Dengan demikian secara keseluruhan, rata-rata jawaban dari responden dengan katagori 1 diatas 60\%. Hal ini menunjukkan bahwa hipotesis pada penelitian ini diterima (terima $\mathrm{Ha}$ tolak Ho), artinya tenaga pendamping mahasiswa berperan baik terhadap Program UPSUS. Hal ini sesusai dengan kriteria pengujian hipotesis yang telah diuraikan pada metode analisis, yaitu jika katagori $1>60 \%$ maka tenaga pendamping mahasiswa berperan baik terhadap Program UPSUS.

\section{KESIMPULAN DAN SARAN}

Berdasarkan analisis deskriptif yang dilakukan maka persepsi petani terhadap tenaga pendamping (Mahasiswa dan Alumni) telah berperan baik pada Program UPSUS.

Sebesar $82 \%$ dari semua responden menunjukan bahwa peran pendamping UPSUS PAJALE di kabupaten Nagan Raya sudah baik dan $18 \%$ responden menunjukan bahwa peran pendamping UPSUS PAJALE di kabupaten Nagan Raya tidak baik.

\section{DAFTAR PUSTAKA}

Departemen Sosial RI. (2005), Pendoman Pendamping Pada Rumah Perlindungan Dan Trauma Center, Jakarta: Depsos RI

Kurniawan, Hakim. 2015. Upaya Khusus (Upsus) Swasembada Pangan 20152017. Artikel. http://biogen.litbang.pertanian.go.id. Di akses 11 Agustus 2015 .

Nazir, M. 2005. Metode Penelitian. Ghalia Indonesia. Jakarta.

Robbins, Stephen P, 2003. Perilaku Organisasi, Jilid 2, PT. Indeks Kelompok Gramedia, Jakarta.

Sugiyono. 2005. Metode Penelitian Administratif. Alfabeta. Bandung.

Sugiyono. 2011. Metode Penelitian Kuantitatif Kualitatif dan $R \& D$. Alfabeta Bandung. 
Suharto, Edi. 2005. Membangun Masyarakat Memberdayakan Masyarakat. Bandung: Rafika Persada. 
Jurnal IImiah Mahasiswa Pertanian Unsyiah

Volume 1, Nomor 1, November 2016 www.jim.unsyiah.ac.id/JFP 